\title{
WSPOMNIENIE O PROFESORZE WOLFGANGU VIERECKU (1937-2018)
}

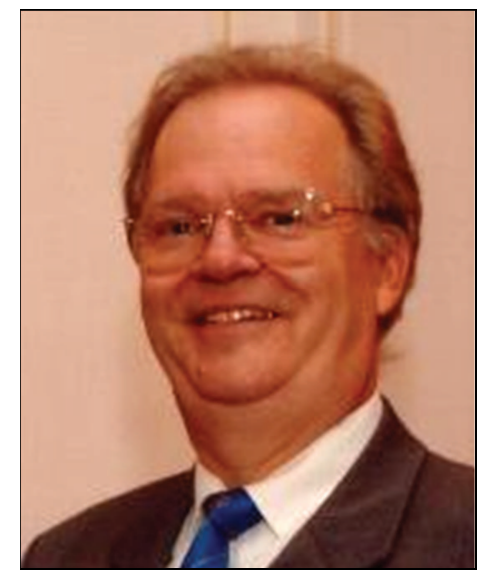

Prof. dr dr hc Wolfgang Viereck

Z głębokim żalem informujemy, że w dniu 04. 09. 2018 r. zmarł Profesor dr hab. Wolfgang Viereck, doktor honorowy UAM (rok nadania Godności: 1999). Profesor Viereck był jednym z najwybitniejszych językoznawców europejskich XX wieku. Był językoznawcą, anglistą i filologiem, żywotnie zainteresowanym współpracą z poznańskim środowiskiem filologicznym, w szczególności z Wydziałem Neofilologii UAM. Rada tegoż Wydziału w uznaniu Jego zasług dla poznańskiego środowiska filologicznego, zwłaszcza dla poznańskiego środowiska językoznawczego, wystąpiła do Senatu UAM z wnioskiem o nadanie Profesorowi Viereckowi Godności Doktora Honorowego, który to wniosek Senat jednogłośnie przyjął i w dniu 24 maja 1999 roku nadał Mu tę najwyższą Godność naszego Uniwersytetu.

Profesor Wolfgang Viereck był wielkim przyjacielem Polski, Poznania i naszej Almae Matris, co podkreślił w swoim przemówieniu (Decani oratio) ówczesny 
dziekan Wydziału Neofilologii UAM, nazywając Profesora Amicus Poloniae et Posnaniae. Profesor Viereck zasiadał w wielu najważniejszych światowych i europejskich gremiach językoznawczych, w tym $\mathrm{m}$. in. był Wice-Prezydentem International Society for Dialectology and Geolinguistics, członkiem Royal Humanistic Academy of Sciences (Uppsala), Prezydentem Atlas Linguarum Europae, Prezydentem International Association of University Professors of English, członkiem International Academy of Sciences, członkiem Academia Europaea. Był autorem wielu fundamentalnych prac z zakresu językoznawstwa historycznego, w tym monumentalnego dzieła pt. Atlas Linguarum Europae (2003. Rzym: Instituto Poligrafico).

Wielokrotnie wizytował UAM, niezwykle chętnie wygłaszając referaty, spotykając się z przedstawicielami poznańskiego środowiska językoznawczego i, co najważniejsze, wspomagając swoim autorytetem wydanie wielu monografii przedstawicieli tegoż środowiska w renomowanym wydawnictwie Peter Lang Verlag. Przez wiele lat mieliśmy zaszczyt korzystania z Jego członkostwa w Komitecie Redakcyjnym czasopisma wydziałowego Scripta Neophilologica Posnaniensia. Był człowiekiem niezwykle życzliwym, pełnym osobistego uroku i nienagannych manier, które to cechy zawsze określają człowieka wielkiego formatu.

Profesor Wolfgang Viereck zapisał się złotymi zgłoskami na niwie współpracy międzynarodowej pomiędzy UAM i Jego macierzystym Uniwersytetem w Bambergu i pozostanie na zawsze we wdzięcznej pamięci poznańskiego środowiska neofilologicznego.

Cześć Jego Pamięci!

Prof. zw. dr hab. Stanisław Puppel Redaktor naczelny Scripta Neophilologica Posnaniensia

\section{Odnośnik bibliograficzny}

Wolfgangus Viereck. Doctor Honoris Causa Universitatis Studiorum Mickiewiczianae Posnaniensis (24 V 1999). 2000. Poznań: Wydawnictwo Naukowe UAM. 